\title{
Perbedaan Hasil Belajar Fisika Siswa untuk Model Pembelajaran Berbasis Proyek dengan Model Pembelajaran Langsung pada Kelas X SMA Negeri 7 Palu
}

\author{
Dian Hardianti, Muhammad Ali, dan Syamsu \\ Hardianti.dian16@gmail.com \\ Program Studi Pendidikan Fisika FKIP Universitas Tadulako \\ Jl. Soekarno Hatta Km. 9 Kampus Bumi Tadulako Tondo Palu - Sulawesi Tengah
}

\begin{abstract}
Penelitian ini bertujuan untuk mengetahui ada tidaknya perbedaan hasil belajar fisika antara model pembelajaran berbasis proyek dengan model pembelajaran langsung pada siswa kelas X SMAN 7 Palu. Jenis penelitian ini adalah kuasi- eksperimen dengan rancangan prates- pascates yang tidak ekuivalen. Penentuan sampel dengan pertimbangan tertentu kemudian dibagi menjadi dua kelas: kelas eksperimen dan kelas kontrol. Instrumen penelitian adalah tes pilihan ganda sebanyak 20 soal. Hasil penelitian ini diuji dengan menggunakan Uji-t (satu pihak). Berdasarkan perhitungan diperoleh nilai $t_{\text {hitung }}=3,02$ ternyata lebih besar dari $t_{\text {tabel }}=1,67$. Hal ini menunjukkan bahwa $t_{\text {hitung }}$ barada diluar daerah penerimaan $\mathrm{H}_{0}$. Sehingga, hipotesis yang menyatakan hasil belajar fisika siswa dengan model pembelajaran berbasis proyek lebih baik daripada hasil belajar fisika siswa yang menggunakan model pembelajaran langsung, diterima pada tingkat kepercayaan 95\%. Sesuai dengan kriteria penerimaan diperoleh hasil bahwa nilai $t_{\text {hitung }}>t_{\text {tabel, }}$ maka dapat disimpulkan hasil belajar fisika antara siswa yang menggunakan model pembelajaran berbasis proyek lebih baik dari siswa yang menggunakan pembelajaran konvensional dengan model pembelajaran langsung (direct instruction).
\end{abstract}

Kata kunci : Hasil belajar fisika, Model pembelajaran berbasis proyek

\section{PENDAHULUAN}

Pendidikan sains adalah salah satu aspek pendidikan yang digunakan sebagai alat untuk mencapai tujuan pendidikan. Hakikatnya sains tidak hanya terdiri dari fakta, konsep, dan teori yang dapat dihafalkan. Seperti yang ditemukan atau dilakukan oleh para ilmuan, akan tetapi yang sangat penting adalah kegiatan atau proses aktif menggunakan pikiran dan sikap ilmiah dalam mempelajari gejala alam yang belum diterangkan melalui percobaan dan penelitian ilmiah. Dengan demikian, tuntutan untuk terus menerus memutakhirkan pengetahuan sains menjadi suatu keharusan ${ }^{[1]}$.

Fisika merupakan ilmu dasar dalam ilmu pengetahuan dan juga ilmu yang banyak melakukan percobaan. Tidak sedikit siswa beranggapan belajar fisika selalu berhadapan dengan sejumlah rumus yang panjang, soal-soal yang rumit, dan kalimat-kalimat yang membingungkan sehingga belajar fisika kurang diminati siswa. Ditambah lagi Penyampaian materi yang dilakukan dengan metode/ model yang sama, yaitu pembelajaran konvensional dimana guru terlalu mendominasi proses belajar mengajar sehingga siswa menjadi pasif, hal ini berdampak pada mutu pendidikan fisika yang menyebabkan hasil belajar siswa rendah. Materi ajar berbeda- beda sehingga penyampaian materi kepada siswa juga bisa dilakukan dengan cara yang berbeda dengan menerapkan model pembelajaran yang membuat peserta didik tertarik untuk belajar. Karena fisika identik dengan konsep untuk membuktikan suatu konsep tersebut maka bereksperimen membuat suatu alat sederhana/ alat peraga menjadi salah satu cara belajar yang menarik dan menyenangkan dapat membantu siswa dalam mempelajari fisika. Proses belajar mengajar di kelas menggunakan model pembelajaran yang sesuai dapat memotivasi siswa untuk giat dalam belajar sehingga dapat meningkatkan hasil belajar siswa. Peneliti coba menerapkan model pembelajaran berbasis proyek di kelas untuk mengetahui perbedaan hasil belajar fisika siswa. Model pembelajaran berbasis proyek merupakan pengembangan dalam mengajar yang diperkenalkan oleh John Dewey. Model Pembelajaran Berbasis Proyek (Project Based 
Learning $=\mathrm{PjBL}$ ) adalah model pembelajaran yang menggunakan proyek/kegiatan sebagai media ${ }^{[2]}$. Pembelajaran berbasis proyek dilakukan untuk memperdalam pengetahuan dan keterampilan yang diperoleh dengan cara membuat karya atau proyek yang terkait dengan materi ajar dan kompetensi yang diharapkan dimiliki oleh siswa. Siswa melakukan kegiatan menyelesaikan masalah, pengambilan keputusan, keterampilan melakukan investigasi, dan keterampilan membuat karya untuk menghasilkan berbagai bentuk hasil belajar ${ }^{[3]}$.

Adapun langkah-langkah operasional model pembelajaran berbasis proyek adalah penentuan proyek, menyusun perencanaan proyek, menyusun jadual, monitoring, presentasi hasil proyek dan evaluasi pengalaman ${ }^{[4]}$.

\section{METODE PENELITIAN}

Desain atau rancangan pada penelitian ini menggunakan "non ekuivalen pretest-posttest design" atau rancangan pretest-posttest yang tidak ekuivalen. Bentuk desainnya disajikan pada Tabel $1^{[5]}$

Tabel 1 Desain Penelitian

\begin{tabular}{lccc}
\hline Group & $\begin{array}{c}\text { Tes } \\
\text { Awal }\end{array}$ & Perlakuan & $\begin{array}{c}\text { Tes } \\
\text { Akhir }\end{array}$ \\
\hline $\begin{array}{c}\text { Kelas } \\
\text { Eksperimen }\end{array}$ & $\mathrm{O}_{1}$ & $\mathrm{X}$ & $\mathrm{O}_{1}$ \\
Kelas Kontrol & $\mathrm{O}_{1}$ & - & $\mathrm{O}_{1}$ \\
\hline
\end{tabular}

Keterangan :

$\mathrm{O}_{1}$ : Tes awal (pretest) dan tes akhir (posttest)

$X$ : Perlakuan untuk kelompok eksperimen dengan menerapkan model pembelajaran berbasis proyek.

Populasi dalam penelitian ini adalah seluruh siswa kelas X SMA Negeri 7 Palu Tahun ajaran 2015/2016. Berdasarkan karakteristik populasi maka pengambilan sampel dilakukan dengan teknik purposive sampling. Untuk menentukan sampelnya yaitu berdasarkan rekomendasi guru $^{[7]}$.

Dua kelas yang dijadikan tempat penelitian ini adalah kelas yang diajar oleh guru yang sama, yaitu kelas $X_{g}$ diberikan model pembelajaran berbasis proyek (kelas eksperimen) dan kelas $X_{h}$ menggunakan pembelajaran konvensional yaitu model direct instruction (kelas kontrol).

Instrumen yang digunakan dalam penelitian ini yaitu tes hasil belajar dalam bentuk pilihan ganda sebanyak 20 item yang terkait dengan materi hukum Newton. Proses analisis tes dilakukan dengan cara uji coba tes/ validitas item menggunakan beberapa uji statistik.

\section{HASIL dan PEMBAHASAN}

Pretest digunakan untuk mengetahui kemampuan awal siswa sebelum mengikuti pembelajaran. Data pretest terdiri dari kelas eksperimen dan kelas kontrol yang masingmasing berjumlah 22 siswa. Adapun data pada hasil penelitian disajikan pada Tabel 2 yang mendeskripsikan skor tes hasil belajar fisika siswa kelas eksperimen dan kelas kontrol. Kemudian berdasarkan $\mathrm{uji}$ normalitas. Uji normalitas pada penelitian ini menggunakan uji Chi-kuadrat dengan kriteria penerimaan $\chi_{\text {Hitung }}^{2}<$

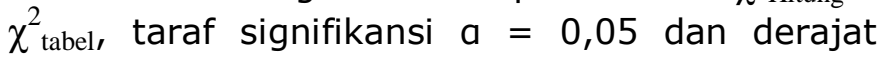
kebebasan $\mathrm{dk}=\mathrm{k}-3$. Hasil uji normalitas yang terlampir pada Tabel 3 diketahui nilai $\chi^{2}$ Hitung $<$

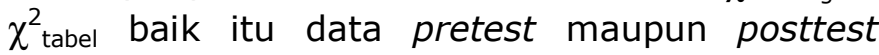
sehingga dapat disimpulkan keduanya berasal dari populasi yang terdistribusi normal.

Tabel 2 Deskripsi skor tes hasil belajar fisika siswa untuk kelas eksperimen dan kelas kontrol

\begin{tabular}{lcccc}
\hline \multirow{2}{*}{ Uraian } & \multicolumn{2}{c}{ Pretest } & \multicolumn{2}{c}{ Posttest } \\
\cline { 2 - 5 } & \multicolumn{2}{c}{ Eksperimen } & Kontrol & Eksperimen Kontrol \\
& 22 & 22 & 22 & 22 \\
Sampel (n) & 10 & 9 & 18 & 17 \\
Nilai maksimum & 2 & 1 & 9 & 8 \\
Nilai minimum & 5,75 & 4,95 & 14,64 & 11,82 \\
Skor rata-rata & 2,20 & 2,19 & 2,48 & 2,43 \\
Standar deviasi & & & &
\end{tabular}

Tabel 3 Hasil uji normalitas pretest-posttest kelas eksperimen dan kelas kontrol

\begin{tabular}{lcccc}
\multirow{2}{*}{ Uraian } & \multicolumn{2}{c}{ Pretest } & \multicolumn{2}{c}{ Posttest } \\
\cline { 2 - 5 } & Eks & Kon & Eks & Kon \\
Nilai $\chi_{\text {hitung }}^{2}$ & 1,86 & 2,17 & 3,74 & 2,55 \\
Nilai $\chi_{\text {tabel }}$ & 5,99 & 5,99 & 5,99 & 5,99 \\
Keputusan & Terdistribusi normal & $\begin{array}{c}5,99 \\
\text { Terdistribusi normal }\end{array}$ \\
\hline
\end{tabular}

Uji homogenitas pada penelitian ini menggunakan uji statistik $F$ dengan taraf signifikansi $a=0,05$ dan data pada uji ini disajikan pada Tabel 4. Berdasarkan kriteria pengambilan keputusan disimpulkan varians antara kelas eksperimen dan kelas kontrol adalah sama atau homogen.

Table 4 Hasil uji homogenitas pretest-posttest kelas eksperimen dan kelas kontrol

\begin{tabular}{ccccc}
\hline \multirow{2}{*}{ Uraian } & \multicolumn{2}{c}{ Pretest } & \multicolumn{2}{c}{ Posttest } \\
\cline { 2 - 5 } Nilai Variansi & Eks & Kon & Eks & Kon \\
\cline { 2 - 5 } & 6,35 & 6,72 & 7,92 & 6,71 \\
\hline
\end{tabular}




$\begin{array}{lcc}\text { Variansi Hitung } & 1,06 & 1,18 \\ \text { Nilai F tabel }(a=0,05) & 2,03 & 2,03 \\ \text { Keputusan } & \text { Homogen } & \text { Homogen }\end{array}$

Peningkatan hasil belajar yang diperoleh dari hasil uji N-Gain kedua kelas dengan nilai rata- rata N-Gain kelas eksperimen sebesar 63 dan kelas kontrol dengan nilai rata- rata N-Gain sebesar 47. Berdasarkan patokan kriteria tingkat gain dimana $30 \leq \mathrm{g}<70$ dinyatakan dalam kategori sedang. Sehingga, kelas eksperimen dinyatakan berada pada kategori sedang begitupun untuk kelas kontrol. Tetapi jika di tinjau secara kuantitatif untuk kelas eksperimen lebih unggul dari kelas kontrol.

Setelah terpenuhinya uji normalitas dan homogenitas, maka dilakukan uji beda rata-rata (satu pihak) atau uji t. Adapun data hasil uji perbedaan rata- rata untuk kedua kelas disajikan dalam Tabel 5.

Tabel 5 Uji Perbedaan Rata-Rata Kelas Eksperimen dan Kelas Kontrol

\begin{tabular}{lllll}
\hline Kelas & $\begin{array}{l}\text { Nilai rata- } \\
\text { rata posttest }\end{array}$ & $t_{\text {hitung }}$ & $\begin{array}{l}t_{\text {tabel }} \\
(\mathrm{a}=0,05)\end{array}$ & Keputusan \\
\hline Eksperimen & 14,64 & 3,02 & 1,67 & $\begin{array}{l}\mathrm{H}_{1} \\
\text { diterima }\end{array}$ \\
Kontrol & 11,82 & & & \\
\hline
\end{tabular}

Tabel 5 menunjukkan nilai $t_{\text {hitung }}=>t_{\text {tabel }}$. Sehingga diperoleh kesimpulan bahwa terdapat perbedaan yang signifikan antara rata- rata nilai kelas eksperimen dan kelas kontrol. Karena sesuai dengan kriteria penerimaan, maka dapat dikatakan bahwa rata-rata hasil belajar antara siswa yang mendapatkan pembelajaran berbasis proyek lebih baik dibanding siswa yang mendapatkan pembelajaran konvensional dengan model direct instruction. Dengan demikian $\mathrm{H}_{0}$ ditolak dan $\mathrm{H}_{1}$ diterima pada tingkat kepercayaan $95 \%$ hal ini menunjukkan bahwa terdapat perbedaan yang signifikan antara ratarata nilai kelas eksperimen dan kelas kontrol.

Hasil penelitian model pembelajaran berbasis proyek pada kelompok eksperimen ini menunjukkan bahwa hasil belajar pada kelompok eksperimen dengan model pembelajaran berbasis proyek dalam konsep hukum Newton lebih baik dibandingkan dengan kelompok kontrol yang dalam pembelajaran menggunakan pembelajaran konvensional. Hal ini sejalan dengan penelitian ${ }^{[2]}$, adapun hasil yang diperoleh dari penelitian ini adalah efek model pembelajaran berbasis proyek terhadap berpikir kreatif siswa menunjukkan bahwa terdapat perbedaan berpikir kreatif siswa antara Model Pembelajaran Berbasis Proyek dengan KWL Worksheet dan Model Pembelajaran Kooperatif dalam pemecahan masalah Fisika. Kemudian, hasil penelitian menunjukkan bahwa hasil belajar kognitif tingkat tinggi fisika menggunakan model pembelajaran berbasis proyek dengan strategi think talk write berbeda dan menunjukkan hasil yang lebih baik dibandingkan dengan pembelajaran konvensional ${ }^{[6]}$.

Berdasarkan hasil dari penelitian- penelitian tersebut diketahui adanya pengaruh positif model pembelajaran berbasis proyek yang mampu mengubah cara belajar siswa menjadi aktif serta dapat meningkatkan hasil belajar fisika. Saat kegiatan belajar mengajar berlangsung memberikan pengalaman tersendiri kepada siswa dalam pembelajaran dan praktik. Suasana belajar menjadi menyenangkan, sehingga siswa maupun guru menikmati proses pembelajaran. Inilah salah satu kelebihan dari model pembelajaran berbasis proyek yang membuat hasil belajar lebih baik karena dapat memotivasi siswa sehingga meningkatkan perhatian siswa untuk belajar fisika.

Hasil penelitian menggunakan model pembelajaran berbasis proyek pada kelompok eksperimen menunjukkan peningkatan hasil belajar fisika. Jika ditinjau secara kuantitatif untuk kelas eksperimen diperoleh nilai rata-rata $\mathrm{N}-$ Gain yang lebih tinggi dari kelas kontrol. Kemudian hasil uji perbedaan rata-rata, diperoleh bahwa nilai thitung $>t_{\text {tabel }}$. Sesuai dengan kriteria penerimaan dapat disimpulkan bahwa rata-rata hasil belajar fisika antara siswa yang mendapatkan pembelajaran berbasis proyek lebih baik daripada siswa yang mendapatkan pembelajaran konvensional dengan model pembelajaran langsung. Penggunaan model pembelajaran berbasis proyek dalam proses belajar mengajar di kelas $X$ SMAN 7 Palu, membuktikan hipotesis penelitian bahwa terdapat perbedaan hasil belajar fisika antara model pembelajaran berbasis proyek dengan pembelajaran konvensional dengan model pembelajaran langsung (direct instruction).

Model pembelajaran berbasis proyek dilakukan untuk memperdalam pengetahuan dan keterampilan yang diperoleh dengan cara membuat karya atau proyek yang terkait dengan materi ajar ${ }^{[3]}$. Model pembelajaran berbasis proyek adalah penggerak yang unggul untuk membantu siswa bertanggung jawab dengan tugas dan menggunakan sumber- sumber yang 
terbatas secara efektif serta bekerjasama dalam kelompok (social).

\section{KESIMPULAN}

Berdasarkan hasil analisa data penelitian disimpulkan bahwa terdapat perbedaan hasil belajar fisika antara model pembelajaran berbasis proyek dengan model pembelajaran langsung pada siswa kelas X SMA Negeri 7 Palu. $\mathrm{Hal}$ ini ditunjukkan dengan kriteria penerimaan Ho adalah $t_{\text {hitung }}=3,02>t_{\text {tabel }}=1,67$.

\section{DAFTAR PUSTAKA}

${ }^{[1]}$ Rahmawati, Dini (2011). Pengaruh Model Pembelajaran Berbasis Proyek Terhadap Hasil Belajar Fisika Siswa SMPN 48 Jakarta. Skripsi tidak diterbitkan. UIN Syarif Hidayatullah Jakarta.

${ }^{[2]}$ Mihardi, Satria, Mara Bangun Harahap dan Ridwan Abdullah Sani. (2013). The Effect of Project-Besed Learning Model with KWL Worksheet on Student Creative Thinking Process in Physics Problems. Journal of Education and Practice, [Online], Vol. 4. No. 25, Tersedia: www.iiste.org, [13 November 2014]

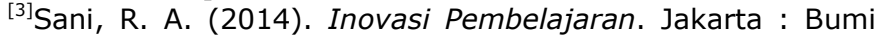
Aksara

${ }^{[4]}$ Kemdikbud. (2013). Model Pengembangan Berbasis Proyek (Project Based Learning). [Online], Tersedia: http://www.eurekapendidikan.com, [27 November 2014]

[5]Sugiyono. (2011). Metodelogi Penelitian Pendidikan (Pendekatan Kuantitatif, Kualitatif, dan R\&D). Bandung: Alfabeta.

${ }^{[6]}$ Ramadhani, Irham dan Moltan. (2015). Efek Model Pembelajaran Berbasis Proyek dengan Strategi Think Talk Write dan Kreativitas IImiah Terhadap Hasil Belajar Kognitif Tingkat Tinggi Siswa SMA Pada Pelajaran Fisika. Jurnal Pendidikan Fisika, [Online], Vol. 4. No. 1, Tersedia: http://jurnal.unimed.ac.id, [7 Desember 2015] 